\title{
Toxicity Test of Apricot and Cassava by Using Albino Rats as an Experimental Model
}

\author{
Laipubam Kamala Devi ${ }^{1}$, Maibam Haripriya Devi ${ }^{2}$, Potsangbam Kumar $\operatorname{Singh}^{1, *}$ \\ ${ }^{1}$ Department of Life Sciences, Manipur University, Canchipur, Imphal -795003, Manipur, India \\ ${ }^{2}$ Department of Botany, Manipur College, Imphal -795001, Manipur, India \\ *Corresponding author, Contact:+91-9774011289, and E-mail: potsangbamk031@gmail.com
}

\begin{abstract}
Toxicity tests of Apricot (Prunus armeniaca L.; Prunus persica (L.) Stokes) seed, and Cassava (Manihot esculenta Crantz.) root, were studied by using albino rats as an experimental model. The specimens of liver taken from the albino rats after 30 days diet on crude extract seeds of Apricot show slight enlargement, increase in weight and pallor with increased turgor as compared to the specimens from the albino rats on normal diet. Histological sections of the liver taken from 30 days diet, show small clear vacuoles within the cytoplasm representing distended and pinched off segment of endoplasmic reticulum. There were swelling and increased eosinophillic staining of the cells in a panlobular fashion. The features were of hydropic change or vacuolar degeneration. The results of the study shows the degenerative changes present in the liver persisted in focal areas in the mice fed on apricot seed and in the periportal and peribular areas in the mice fed on cassava root.
\end{abstract}

Key words: toxicity test, apricot seed, cassava root, experimental model

\section{Introduction}

Toxicity of some edible plant parts of many families were studied by various researchers. Studies were carried out in six selected Rosaceous fruits Viz., (Docynia indica (Wall.) Decne., Prunus armeniaca L., Prunus domestica L. (VAR 1 \& VAR II) and Prunus persica (L.) Stokes (VAR $1 \&$ VAR II), which are found in Manipur and reported that Vitamin C is more responsible for free radical scavenging activity and different phenolic compounds with their antioxidant activity [1]. Considerable amount of plant metabolites like total phenols, tannins, and flavonoids are present in fruits of Rosaceae family, which is consumed in large amounts in Manipur, however, prussic acids are present only in the seed [1], [2].

Among the nine selected plants for biochemical analysis, no plant showed an overall maximum biochemical contents as a whole; however human body can get mineral elements from these plant sources [3]. Evaluation of nutritive and anti-nutritional value of these selected samples provides an easily accessible natural source that could be used as food supplement [2]. Though all the analysed fruits contain saponins, phytates and tannins, it was reported that the edible pulp of the fruits namely, Docynia indica, Prunus armeniaca, $P$. domestica, $P$. persica are useful for consumption and the seed of these fruits were dangerous to health if taken at a large quantity [2]. Fresh consumption of Manihot esculenta Crantz., root in large quantity is dangerous to human being [2].

* Potsangbam Kumar Singh. Tel.: +919774011289; fax: +91385 2435 145. E-mail address: potsangbamk031@gmail.com 
The toxicity of $\mathrm{HCN}$, a role in plant protection against herbivores, pathogens, and competitors is appealing. Indeed it favours a defence function against certain animals including insects [4], [5], [6]. Species showing cyanogenic polymorphism have frequently been exploited to investigate such plant-herbivore interactions. Cyanogenic glycosides are constitutive defence compounds found in about 5\% of all plants [5], [7]. In the same way, toxic cyanide is released when the plant cut into small pieces during food preparation and the resulting hydrogen cyanide is easily removed by cooking in water since it is volatile [8]. Accumulation of cyanogenic glucosides in certain angiosperm seeds provide a storage deposit of reduced nitrogen and sugar for the developing seedling [9]. Different species of plants present different cyanogenic glucosides like Cassava, barley [10], [11], [12]. This study was, aimed at determining the toxicity of apricot seed and cassava root by using albino rats as an experimental model.

\section{Materials and Methods}

\subsection{Source of Plant Materials}

Two Rosaceae plants seeds of Prunus persica (L.) Stokes., and Prunus armeniaca L. and roots of Manihot esculenta Crantz. under Euphorbiaceae family, were selected for the present study (Table 1 and Fig. 1).

Table 1. Selected Plants Species along with their local names, locality and their Voucher Number

\begin{tabular}{|l|l|l|l|}
\hline \multicolumn{1}{|c|}{ Species } & \multicolumn{1}{|c|}{$\begin{array}{c}\text { Local } \\
\text { Name }\end{array}$} & \multicolumn{1}{|c|}{ Locality } & \multicolumn{1}{|c|}{$\begin{array}{l}\text { Voucher } \\
\text { Number }\end{array}$} \\
\hline $\begin{array}{l}\text { Prunus } \\
\text { armeniaca } \text { L. }\end{array}$ & Malhei & $\begin{array}{l}\text { Elang- } \\
\text { Khanpokpi }\end{array}$ & $\begin{array}{l}\text { 000291 } \\
\text { (MUMPs) }\end{array}$ \\
\hline $\begin{array}{l}\text { Prunus persica } \\
\text { (L.) Stokes }\end{array}$ & Chumbrei & Canchipur & $\begin{array}{l}\text { 000294 } \\
\text { (MUMPs) }\end{array}$ \\
\hline $\begin{array}{l}\text { Manihot } \\
\text { esculenta } \text { Crantz }\end{array}$ & U- Mangra & $\begin{array}{l}\text { Elang- } \\
\text { Khanpokpi }\end{array}$ & 000297(MUMPs) \\
\hline
\end{tabular}

\subsection{Toxicity Test: Treatment}

Toxicity test using rats (Rattus norvegicus) as experimental model was followed, with slight modification [13]. Animal care and experimental protocols were performed in accordance with the guidelines of the Institutional Animal Ethical Committee (IAEC). Experimenters on rats were conducted with the approval of Manipur University Animal Ethical Committee, Order No. M.U/3-5/05/Aca. L. Sc., of Institutional Animal Ethical Committee (IAEC). The mortality rate, morphological changes and body weight of each group was studied for three months. Rats were obtained from RIMS (Regional Institute of Medical Sciences, Imphal, Manipur).

2.3 Feeding trial experiment in Albino rats using different doses of crude extracts of $P$. armeniaca seed. $P$. persica seed and M. esculenta root and NaCN solution

Rats were divided into two batches. First batch divided in to eight groups of six rats each, namely group I, II, III, IV, V, VI, VII, and VIII. They were housed in room temperature and fed with basal diet free access of water. 

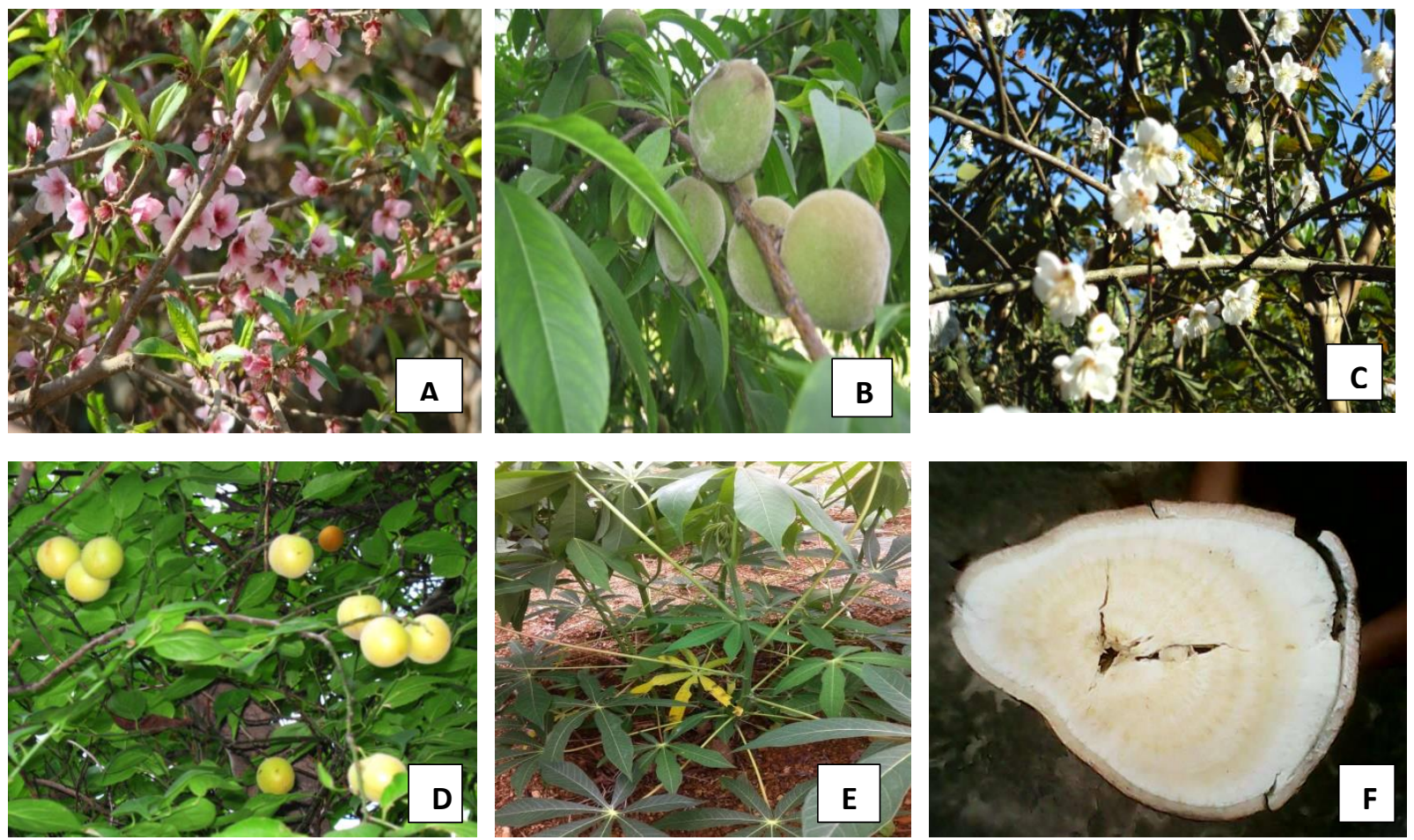

Fig. 1. Plants Species: A. Prunus persica (L.) Stokes, plant and B. fruits, C. P. armeniaca L. plant and D. fruits, E. Manihot esculenta Crantz, plant and F. root section.

\subsection{Preparation of samples}

Seeds are taken out from kernel and they are air dried and grown into powder form using pestle and mortar. M. esculenta root were collected and sliced off, than they are air dried and ground into powder form.

\section{Batch I}

I. The rats of Group I was fed with standard diet and distilled water only.

II. The rats of Group II were fed standard diet and $\mathrm{NaCN}$ solution $(1 \mu \mathrm{l} / \mathrm{ml})$.

III. The rats of Group III were fed with standard diet and crude extract of $P$. armeniaca seed with $500 \mathrm{mg}$.

IV. The rats of Group IV were fed with standard diet and crude extract of P. persica seed with 500mg.

V. The rats of Group V were fed with standard diet and crude extract of $M$, esculenta root with $500 \mathrm{mg}$.

VI. The rats of Group VI were fed with standard diet and crude extract of $P$. armeniaca seed with $1000 \mathrm{mg}$.

VII. The rats of Group VII were fed with standard diet and crude extract of P. persica seed with $1000 \mathrm{mg}$.

VIII. The rats of Group VIII were fed with standard diet and crude extract of $M$. esculenta root with $1000 \mathrm{mg}$.

Batch II

I. This group kept for 90 days after feeding for examine the improvement of the tissue or organ. 
II. The rats of Group I were fed with standard diet and crude extract of $P$. armeniaca seed with $1000 \mathrm{mg}$.

III. The rats of Group II were fed with standard diet and crude extract of $P$. persica seed with $1000 \mathrm{mg}$.

IV. The rats of Group III were fed with standard diet and crude extract of $M$. esculenta root with $1000 \mathrm{mg}$.

All the batches were fed once a day for a period of 30 days. And body weights of the rats were measured on weekly basis. On the completion of the treatment period, four rats from each group were sacrificed and blood samples were collected by cardiac punctured technique and organs were excised immediately and washed with physiological saline. For next 90 days the remaining rats from Batch II which were given normal diet and on the completion of the duration, all the rats were dissected and organs were excised and only histopathological investigation were carried out.

\subsection{Histopathological Investigation}

At the end of treatment the rats were sacrificed under anaesthesia condition. The liver, kidney, spleen were excised immediately and thoroughly washed with ice cold physiological saline water, and a small portion of these organs was quickly fixed in $10 \%$ formalin, then, the tissues were processed by standard histopathological technique [14]. The tissues were dehydration through graded isopropyl alcohol, cleaning through xylene and impregnated in paraffin wax for $2 \mathrm{hr}$. Wax blocks were made for microtome section cutting and stained by haematoxlin eosin method and photographed with the help of a tri-ocular micro-photographic microscope.

\subsection{Tissue dehydration procedure}

After dissection the liver and kidney were taken for dehydration procedure to prepared slide for histopathological studies. The tissues were subjected into stepwise procedure as given below:

1. In $10 \%$ formalin for $4 \mathrm{hr}$.

2. $70 \%$ alcohol for $1 \mathrm{hr}$.

3. $80 \%$ alcohol for $1 \mathrm{hr}$.

4. $90 \%$ alcohol for $1 \mathrm{hr}$.

5. $100 \%$ alcohol for $1 \mathrm{hr}$.

6. $100 \%$ alcohol for $1 \mathrm{hr}$.

7. $100 \%$ for 1 and half $\mathrm{hr}$.

8. Copper sulphate for 1 and half hr. (indicator).

9. Xylene for 1 and half hr. (clearing).

10. Xylene + wax (50:50) for 1 and half hr.

\subsection{Block making}

After dehydration procedure, the tissue is put in L-shape block containing paraffin wax for 3-6 min. The block is trimmed and put in $4 \%$ phenol for $30 \mathrm{~min}$. For firmness the tissue is then put into ice for $10-15 \mathrm{~min}$, the block is put into section cutting, section are put into water bath and good section are selected and mount in a glass slide. The slide is put into hot air oven at $60-62^{\circ} \mathrm{C}$ for $30 \mathrm{~min}$ and then dipped in xylene for $5-10 \mathrm{~min}$ for deparaffinization, then rehydration of the tissue in the slide is done by dipping the slide in $100 \%, 90 \%, 80 \%, 70 \%, 60 \%$ and $50 \%$ alcohol in series for 5-10min each, the slide is wash in tap water then in haematoxylin then again wash in tap water. De-paraffination was done in $1 \%$ acid alcohol $(70 \%$ alcohol $+1 \mathrm{ml} \mathrm{HCl})$, by dipping for $(2-3 \mathrm{sec})$. Bluing is done by dipping (1sec.) in $1 \%$. Dehydration of the slide is done by dipping it in $70 \%, 60 \%, 50 \%, 40 \%, 30 \%$, $20 \%$ and $10 \%$ alcohol respectively for 5-10 min each. After dehydration the slide is clear in 
xylene by dipping it for few sec, and then mounts it in DPX. The slide is ready for study under high power microscope.

\subsection{Haematological studies}

For haematological analysis $3 \mathrm{ml}$ of blood were collected by cardiac puncture into heparinised vials and store at $10^{\circ} \mathrm{C}$ for analysis the same day. Haemoglobin concentration $(\mathrm{Hb})$, red blood cell (RBC), and white blood cell (WBC), haematocrit (PVC) and differential cell count were conducted [15], [16].

\subsection{Estimation of total haemoglobin}

Haldane's haemoglobinometer was used for the estimation of haemoglobin. Five drops of $\mathrm{N} / 10 \mathrm{HCl}$ was put in the graduated tube. Blood was drawn in the blood sucking micropipette up to the mark of $20 \mathrm{~mm}^{3}$. The blood of micropipette was added to the N/10 $\mathrm{HCl}$ solution in the graduated tube. It was then stirred with the help of a glass rod and allowed to stand at least $10 \mathrm{~min}$. Then the acid haematin solution was gradually diluted by distilled water in a drop wise manner till the colour matched with that of the standard comparison tubes. The readings in the graduated tube give the haemoglobin concentration in $\mathrm{g} / \mathrm{dl}$.

\subsection{Total count of $R B C$ and $W B C$}

Total count of RBC and WBC was done by using a haemocytometer (Felin-optic, GDR). For total count of RBC, the heparinised blood was drawn in RBC counting pipette up to 0.5 mark taking care of air bubbles were not included. The pipette was transferred to the container of Hayem's solution which carefully sucked up to the 101 mark. The pipette was held horizontally between the forefingers and rotated several times so that blood thoroughly mixed with Hayem's fluid. In this dilution of blood became 200 times. RBC was counted in 5big square. Each square measured $\frac{1}{5} \times \frac{1}{5}=\frac{1}{25}$ sq.mm. Each of these squares was further divisible into 16 smaller squares, so that there are 400 smallest squares in all. The total number of RBC per $\mathrm{mm}^{3}$ was calculated multiplying by 10,000 to the number of cell found in 80 small squares. For the total count of WBC, blood was sucked exactly up to the mark $0.5 \mathrm{~cm}$ of the WBC pipette. The graduations on the pipette for WBC are 0.5 mark and Turk' fluid was drawn up to the mark II and mixed, so that blood thoroughly mixed with Turk's fluid. WBC counting was done by counting 4 big squares in four corners, out of 9 big squares of Neubaver ruling. Number of WBC per $\mathrm{mm}^{3}$ was calculated multiplying by 200 to the number of cells counting 4 big squares.

\subsection{Differential count of white blood corpuscles}

A thin slide was prepared and stained with Wright's stain to study a differential leukocyte count. A drop of blood was placed on a clean dry slide and a thin film was prepared. The film was air-dried and stained the blood film with Wright's stain along with an equal amount of water. After $10 \mathrm{~min}$, the slides were washed in running tap water and then allowed to dry. The cyto-morphological picture, differential counts were studied under a compound research microscope (C.Z.Vertical compound Light Microscope). Counting was done in a longitudinal strip of the blood film with various kinds of white blood corpuscles from top to the bottom and calculates the percentage.

\subsection{Statistical Analysis}

The results of biochemical studies were provided as mean \pm SEM and they are analysed for their significance difference by using one way analysis of variance (ANOVA) test followed by Tukey's significant difference post hoc comparison. Pearson Correlation values among the parameters taken up for biochemical analysis were performed using SPSS version 15 and their values were presented in the form of a table. 


\section{Results and Discussion}

The present experiment was carried out to study to which extent the toxic components effect human health by using albino rats as experimental model. The experimental rats shows marked morphological and behavioural changes associated with retarded growth, falling of hairs, sticking of hairs in clump spreading to neck and head region, reduced reaction to noise, slow movement and resting at the corner of cages.

Table 1 shows the body weight for the experimental rats fed with different samples at two different doses and $\mathrm{NaCN}$ solution. The body weights for the experimental rats show different weight loss. Only the control group shows normal behaviour and weight gain. No mortality of rats was observed during the experimental period. During the experiment, except the control groups, the rats are loss of appetite with low intake of food.

Table 2 presents the data of blood parameters and indices obtained for rats fed with different crude samples and the values obtained for rats fed with standard diet (control group) and $\mathrm{NaCN}$ solution (Gr. II) fed. The groups which received the $\mathrm{NaCN}$ solution and Manihot esculenta root (Group VIII $1 \mathrm{~g} / \mathrm{kg} \mathrm{BW}$ ) showed decrease in the haemoglobin content as compared with the control group. Haemoglobin content in control group, group III, group IV and group $\mathrm{V}$ are not significantly different. In the control groups, total leukocyte counts were 11200 cells/cu mm which are shown in Table 2.

However, in the $\mathrm{NaCN}$ feeding rats, the content of total leukocyte were 3000 cells/cu mm. The total leukocyte count in the group III, IV and V were decreased from control groups and group VI, VII were increased than control group, group VIII has similar total leukocyte count with control group. Total lymphocyte count of control group was 7355 cells/cu $\mathrm{mm}$ and $\mathrm{NaCN}$ feeding rats were 2035 cells/cu $\mathrm{mm}$. The total lymphocyte count of rats of two different doses was increased from the control group as shown in Table 2.

Table 1. Weight of rats as affected by the oral administration of sample (crude extracts)

\begin{tabular}{|l|c|c|c|c|c|c|}
\hline Dose & Groups & Initial & First week & $\begin{array}{c}\text { Second } \\
\text { week }\end{array}$ & $\begin{array}{c}\text { Third } \\
\text { week }\end{array}$ & $\begin{array}{c}\text { Fourth } \\
\text { week }\end{array}$ \\
\hline & Control Gr i & $171.66^{\mathrm{a}}$ & $178^{\mathrm{a}} \pm 5.773$ & $180.33^{\mathrm{a}} \pm$ & $185.33^{\mathrm{a}}$ & $191.67^{\mathrm{a}} \pm$ \\
& & \pm 4.409 & $126.7^{\mathrm{b}} \pm$ & 6.064 & \pm 5.811 & 5.487 \\
& $\mathrm{NaCN}(1 \mu \mathrm{gg} /$ & $127.33^{\mathrm{b}}$ & 9.139 & $125.43^{\mathrm{b}} \pm$ & $124^{\mathrm{b}} \pm$ & $119.67^{\mathrm{b}}$ \\
& $\mathrm{ml}) \mathrm{Gr}$ ii & \pm 9.330 & & 9.276 & 8.717 & \pm 7.796 \\
\hline $0.5 \mathrm{~g} /$ & Gr iii & $85^{\mathrm{c}} \pm 2.886$ & $82.67^{\mathrm{c}} \pm$ & $82^{\mathrm{c}} \pm 3.055$ & $80.6^{\mathrm{c}} \pm$ & $79^{\mathrm{c}} \pm 3.455$ \\
$\mathrm{~kg}$ & Gr iv & $106.3^{\mathrm{d}} \pm$ & $3.282^{\mathrm{c}}$ & $99.67^{\mathrm{c}} \pm$ & 2.7 & $93.33^{\mathrm{c}}$ \\
$\mathrm{BW}$ & Gr v & 0.881 & $103.67^{\mathrm{c}} \pm$ & 0.881 & $96^{\mathrm{c}} \pm$ & \pm 1.201 \\
& & $91^{\mathrm{bc}} \pm 3.785$ & $0.667^{\mathrm{c}}$ & $88^{\mathrm{c}} \pm 3.055$ & 1.154 & $85.33^{\mathrm{c}} \pm$ \\
& & & $89.66^{\mathrm{c}} \pm$ & & $86.67^{\mathrm{c}} \pm$ & 2.403 \\
& & & $3.282^{2}$ & & 2.667 & \\
\hline $1 \mathrm{gm} /$ & $\mathrm{Gr}$ vi & $195.67^{\mathrm{e}} \pm$ & $190.33^{\mathrm{a}} \pm$ & $188^{\mathrm{a}} \pm$ & $183^{\mathrm{a}} \pm$ & $181^{\mathrm{a}} \pm$ \\
$\mathrm{kg}$ & $\mathrm{Gr}$ vii & 3.382 & 3.179 & 2.645 & 2.185 & 1.527 \\
$\mathrm{BW}$ & $\mathrm{Gr}$ viii & $169^{\mathrm{a}} \pm$ & $167.6^{\mathrm{a}} \pm$ & $162^{\mathrm{a} \mathrm{b}} \pm$ & $161^{\mathrm{d}}$ & $159^{\mathrm{d}} \pm 1.527$ \\
& & 2.081 & 2.333 & 2.905 & \pm 1.527 & $130.33^{\mathrm{b}} \pm$ \\
& & $139^{\mathrm{bc}} \pm$ & $137^{\mathrm{b}} \pm 1.527$ & $135.6^{\mathrm{b}} \pm$ & $132^{\mathrm{b}} \pm$ & 0.881 \\
& & 2.081 & & 1.333 & 1.452 & \\
\hline
\end{tabular}

*Data presented as mean \pm SEM. Data were analysed by ANOVA and within each column different letters indicate statistically different values according to post-hoc comparison (Tukey HSD) at $\mathrm{P}<0.05$. 
Table 2. Haematological values of rats treated with crude extract of different samples at doses of 0.5 and $1 \mathrm{~g} / \mathrm{kg}$ bw for 30 days compared with controls

\begin{tabular}{|c|c|c|c|c|c|c|c|c|c|c|}
\hline \multirow[t]{2}{*}{ Dose } & \multirow[t]{2}{*}{ Group } & \multirow{2}{*}{$\begin{array}{l}\text { aemogl } \\
\text {-obin } \\
\text { g }(\%)\end{array}$} & \multirow[b]{2}{*}{$\begin{array}{l}\text { Total } \\
\text { leukoc- } \\
\text { yte } \\
\text { cells/cu } \\
\text { mm }\end{array}$} & \multirow[b]{2}{*}{$\begin{array}{l}\text { Total } \\
\text { lymphocy } \\
\text {-te count } \\
\text { cells /cu } \\
\text { mm }\end{array}$} & \multicolumn{3}{|c|}{ Differential leucocyte count } & \multirow{2}{*}{$\begin{array}{l}\text { PVC } \\
(\%)\end{array}$} & \multirow{2}{*}{$\begin{array}{l}\text { MCH } \\
(\%)\end{array}$} & \multirow{2}{*}{$\begin{array}{c}\mathrm{MCHC} \\
(\%)\end{array}$} \\
\hline & & & & & $\begin{array}{c}\text { Lymphocy } \\
\text {-tes }(\%)\end{array}$ & $\begin{array}{c}\text { Mono } \\
\text {-cytes } \\
(\%)\end{array}$ & $\begin{array}{c}\text { Eosino } \\
\text {-phil } \\
(\%)\end{array}$ & & & \\
\hline & $\begin{array}{c}\text { Control } \\
\text { Gr. I }\end{array}$ & $\begin{array}{c}13.80^{\mathrm{a}} \\
\pm \\
0.152\end{array}$ & $\begin{array}{c}11200^{\mathrm{a}} \\
\pm \\
6.227\end{array}$ & $\begin{array}{c}3120^{\mathrm{a}} \\
\pm \\
0.026\end{array}$ & $\begin{array}{c}76^{\mathrm{a}} \\
\pm \\
0.260\end{array}$ & $\begin{array}{c}3.00^{\mathrm{a}} \\
\pm \\
0.328\end{array}$ & $\begin{array}{c}2.15^{\mathrm{a}} \\
\pm \\
\pm \\
0.008\end{array}$ & $\begin{array}{c}40.21^{\mathrm{a}} \\
\pm \\
0.008\end{array}$ & $\begin{array}{c}28.80 \\
\pm \\
0.008\end{array}$ & $\begin{array}{c}33.56 \\
\pm \\
0.121\end{array}$ \\
\hline & $\begin{array}{c}\mathrm{NaCN} \\
(1 \mu \mathrm{g} / \mathrm{m}) \\
\text { Gr. II }\end{array}$ & $\begin{array}{c}11.00^{\mathrm{b}} \\
\pm \\
0.088 \\
\end{array}$ & $\begin{array}{c}3000^{\mathrm{b}} \pm \\
4.484\end{array}$ & $\begin{array}{c}815^{\mathrm{b}} \\
\pm \\
2.886 \\
\end{array}$ & $\begin{array}{c}52.5^{\mathrm{b}} \pm \\
0.345\end{array}$ & $\begin{array}{c}2.90^{\mathrm{a}} \\
\pm \\
0.120 \\
\end{array}$ & $\begin{array}{c}2.80^{b} \\
\pm \\
0.028\end{array}$ & $\begin{array}{c}33.4^{\mathrm{bc}} \\
\pm \\
0.031\end{array}$ & $\begin{array}{c}27.50 \\
\pm \\
0.017\end{array}$ & $\begin{array}{c}33.19 \\
\pm \\
0.159\end{array}$ \\
\hline \multirow[t]{3}{*}{$\begin{array}{l}0.5 \mathrm{~g} \\
\mathrm{~m} / \mathrm{kg} \\
\mathrm{BW}\end{array}$} & Gr. III & $\begin{array}{c}13.80^{\mathrm{a}} \\
\pm \\
0.166\end{array}$ & $\begin{array}{c}8690^{\mathrm{c}} \\
\pm \\
14.193\end{array}$ & $\begin{array}{c}2780^{\mathrm{c}} \\
\pm \\
2.851\end{array}$ & $\begin{array}{c}69.20^{\mathrm{c}} \\
\pm \\
0.664\end{array}$ & $\begin{array}{c}1.00^{\mathrm{b}} \\
\pm \\
0.033\end{array}$ & $\begin{array}{c}2.60^{b} \\
\pm \\
0.330\end{array}$ & $\begin{array}{c}41.60^{c} \\
\pm \\
0.260\end{array}$ & $\begin{array}{c}28.60 \\
\pm \\
0.120\end{array}$ & $\begin{array}{c}34.50 \\
\pm \\
0.231\end{array}$ \\
\hline & Gr. IV & $\begin{array}{c}14^{\mathrm{a}} \\
\pm \\
0.057\end{array}$ & $\begin{array}{c}8200^{\mathrm{d}} \\
\pm \\
5.773\end{array}$ & $\begin{array}{c}3680^{\mathrm{d}} \\
\pm \\
4.409\end{array}$ & $\begin{array}{c}68^{\mathrm{c}} \\
\pm \\
0.120\end{array}$ & $\begin{array}{c}2.00^{\mathrm{c}} \\
\pm \\
0.033\end{array}$ & $\begin{array}{c}1.85^{\mathrm{a}} \\
\pm \\
0.037\end{array}$ & $\begin{array}{c}39.83^{\mathrm{a}} \\
\pm \\
0.233\end{array}$ & $\begin{array}{c}28.50 \\
\pm \\
0.088\end{array}$ & $\begin{array}{c}33.60 \\
\pm \\
0.175\end{array}$ \\
\hline & Gr. V & $\begin{array}{c}14.00^{\mathrm{a}} \\
\pm \\
0.08 \\
\end{array}$ & $\begin{array}{c}10700^{\mathrm{e}} \\
\pm \\
3.710\end{array}$ & $\begin{array}{c}3100^{\mathrm{a}} \\
\pm \\
5.773 \\
\end{array}$ & $\begin{array}{c}66.25^{\mathrm{d}} \\
\pm \\
0.120\end{array}$ & $\begin{array}{c}4.00^{\mathrm{d}} \\
\pm \\
0.65\end{array}$ & $\begin{array}{c}4.00^{c} \\
\pm \\
0.038\end{array}$ & $\begin{array}{c}41.40^{\mathrm{a}} \\
\pm \\
0.261\end{array}$ & $\begin{array}{c}28.40 \\
\pm \\
0.01\end{array}$ & $\begin{array}{c}33.88 \\
\pm \\
0.041\end{array}$ \\
\hline \multirow[t]{3}{*}{$\begin{array}{l}1 \mathrm{gm} / \\
\mathrm{kg} \\
\mathrm{BW}\end{array}$} & Gr. VI & $\begin{array}{c}13.00^{\mathrm{c}} \\
\pm \\
0.057\end{array}$ & $\begin{array}{c}15000^{\mathrm{f}} \\
\pm \\
57.735\end{array}$ & $\begin{array}{l}4200 \pm \\
5.8738\end{array}$ & $\begin{array}{c}64.60^{\mathrm{c}} \\
\pm \\
0.338\end{array}$ & $\begin{array}{c}7.00^{\mathrm{e}} \\
\pm \\
0.027\end{array}$ & $\begin{array}{c}4.00^{\mathrm{d}} \\
\pm \\
0.038\end{array}$ & $\begin{array}{c}40.20^{\mathrm{ac}} \\
\pm \\
0.090\end{array}$ & $\begin{array}{c}28.80 \\
\pm \\
0.142\end{array}$ & $\begin{array}{c}32.88 \\
\pm \\
0.030\end{array}$ \\
\hline & Gr. VII & $\begin{array}{c}13.25^{\mathrm{c}} \\
\pm \\
0.088\end{array}$ & $\begin{array}{c}16800^{\mathrm{g}} \\
\pm \\
6.641\end{array}$ & $\begin{array}{c}1660^{\mathrm{f}} \\
\pm \\
4.415\end{array}$ & $\begin{array}{c}66.00^{\mathrm{d}} \\
\pm \\
0.284\end{array}$ & $\begin{array}{c}6.00^{\mathrm{f}} \\
\pm \\
0.038\end{array}$ & $\begin{array}{c}4.95^{\mathrm{c}} \\
\pm \\
0.031\end{array}$ & $\begin{array}{c}40.00^{\mathrm{a}} \\
\pm \\
0.008\end{array}$ & $\begin{array}{c}28.60 \\
\pm \\
0.029\end{array}$ & $\begin{array}{c}34.38 \\
\pm \\
0.267\end{array}$ \\
\hline & $\begin{array}{l}\text { Gr. } \\
\text { VIII }\end{array}$ & $\begin{array}{c}12.90^{\mathrm{c}} \\
\pm \\
0.115\end{array}$ & $\begin{array}{c}11200^{\mathrm{a}} \\
\pm \\
6.231\end{array}$ & $\begin{array}{c}3100^{\mathrm{a}} \\
\quad \pm \\
28.480 \\
\end{array}$ & $\begin{array}{c}64.00^{\mathrm{e}} \\
\pm \\
0.035\end{array}$ & $\begin{array}{c}8.00^{\mathrm{g}} \\
\pm \\
0.020 \\
\end{array}$ & $\begin{array}{l}6.15^{\mathrm{e}} \pm \\
0.082\end{array}$ & $\begin{array}{c}39.70^{\mathrm{a}} \\
\pm \\
0.482\end{array}$ & $\begin{array}{c}28.66 \\
\pm \\
0.057 \\
\end{array}$ & $\begin{array}{c}32.65 \\
\pm \\
0.033\end{array}$ \\
\hline
\end{tabular}

*Data presented as mean \pm SEM. Data were analysed by ANOVA and within each column different letters indicate statistically different values according to post-hoc comparison (Tukey HSD) at $\mathrm{P}<0.05$.

The specimens of liver taken from the albino rats after 30 days diet on seeds of $P$. armeniaca show slight enlargement, increase in weight and pallor with increased turgor as compared to the specimens from the albino rats on control group or the same specimens even after 90 days of withdrawal of the respective experimental animals. On the other hand no gross morphological changes are detected in the specimens of kidney after 30 days diet in the experimental or the control group.

Histological examination shows degenerative cells in liver for 30 days diet one $P$. armeniaca seeds (group VI), and M. esculenta root (group VIII). The liver show small clear vacuoles within the cytoplasm representing distended and pinched off segment of endoplasmic reticulum along with over all swelling and increased eosinophillic staining of the of the cells in a panlobular fashion in the rat treated with M. esculenta root (group VIII). The features are of hydropic change or vacuolar degeneration. The degenerative changes present in the liver persisted in focal areas in the mice fed on apricot seed and in the periportal and peribular areas in the mice fed on cassava root Fig. 2 - A, B, C and D. 
After 90 days discontinuance of treatment, $\mathrm{NaCN}$ solution treated groups, $P$. armeniaca seed treated groups and $M$. esculenta root treated groups, the degenerative liver tissue did not reverse to normal condition Fig. 2 - E, F and G. Sections of kidney for all the treatment groups show normal condition with normal histology Fig. 2 - H.

The haemoglobin content was significantly lower in group II and group VIII as compared with control group. The number of white blood cells, which were not significantly different from the controls, reveals the normal functions of the haematological system. However, the packed cell volume of the rats treated with $\mathrm{NaCN}$ was significantly lower than the control group ( $\mathrm{p}<0.05$ ). Lymphocyte count was significantly different compared with control groups. Monocytes content was significantly higher than control group, but group II and group IV were lower than control group. Except group IV the eosinophil content was significantly higher than the control group. Albino rats fed with raw cassava diet and $\mathrm{KCN}$ diet shows a decrease of $\mathrm{Hb}, \mathrm{PCV}$, total serum protein concentration and $\mathrm{T}_{4}$ concentration [17]. Continuous exposure of $\mathrm{HCN}$ through diet may lead to pancreatic diabetics [18].

Histological sections of the liver taken from 30 days diet on crude extract of seeds $P$. armeniaca, $M$. esculenta root show small clear vacuoles within the cytoplasm representing distended and pinched off segment of endoplasmic reticulum along with over all swelling and increased eosinophillic staining of the of the cells in a panlobular fashion in the albino rat fed on cassava root and in the periportal areas of rats fed on $P$. armeniaca seed. The features are of hydropic change or vacuolar degeneration. The degenerative changes present in the liver persisted in focal areas in the mice fed on apricot seed and in the periportal and peribular areas in the mice fed on cassava root. Histological sections of the liver taken after 30 days diet on seeds $P$. armeniaca, $M$. esculenta root show small clear vacuoles within the cytoplasm representing distended and pinched off segment of endoplasmic reticulum along with over all swelling. Albino rats fed with aqueous extract of shoot of Phyllanthus pentandrus Schum. \& Thom (Euphorbiaceae) at different doses and at higher doses $(3000 \mathrm{mg} / \mathrm{kg})$ the liver function of the rats was affected and this indicated that cellular damage to plasma membrane of the rats [19].

\section{CONCLUSIONS}

This research work was conducted to gather information on the toxicity of two species of Apricot seeds and Cassava root by using albino rats as an experimental model. In the present investigation $\mathrm{NaCN}$ diet, shows histological sections of the liver taken from 30 days diet show small clear vacuoles within the cytoplasm representing distended and pinched off segment of endoplasmic reticulum along with over all swelling and increased eosinophillic staining of the of the cells in a panlobular fashion in the albino rat fed on cassava root and in the periportal areas of rats fed on apricot seed. The features are of hydropic change or vacuolar degeneration. The degenerative changes present in the liver persisted in focal areas in the mice fed on apricot seed and in the periportal and peribular areas in the mice fed on cassava root shows the toxicity in the liver cells. Similar experiments of Albino rats fed with raw cassava diet and $\mathrm{KCN}$ diet shows a decrease of $\mathrm{Hb}, \mathrm{PCV}$, total serum protein concentration and $\mathrm{T}_{4}$ concentration [17]. Continuous exposure of $\mathrm{HCN}$ through diet may lead to pancreatic diabetics [18]. Albino rats fed with aqueous extract of shoot of Phyllanthus pentandrus Schum. \& Thom (Euphorbiaceae) at different doses and at higher doses $(3000 \mathrm{mg} / \mathrm{kg})$ the liver function of the rats was affected and this indicated that cellular damage to plasma membrane of the rats [19]. Though, the fruits contain high antioxidant properties, saponins, phytates and tannins, it is found that the edible pulp of the fruits namely Prunus armeniaca, $P$. persica are useful for consumption and the seed of these fruits were dangerous 
to health if taken at a large quantity. Fresh consumption of Manihot esculenta root in large quantity is dangerous to human beings [1], [2]. It can be suggested that, not only the Armed forces who are doing their duties in the jungles of North-East India, should be very much aware of these threats for their personal safety during specific operations [20], but also the tribal folks who are jungle dwellers should also take care the toxicity of these plants.

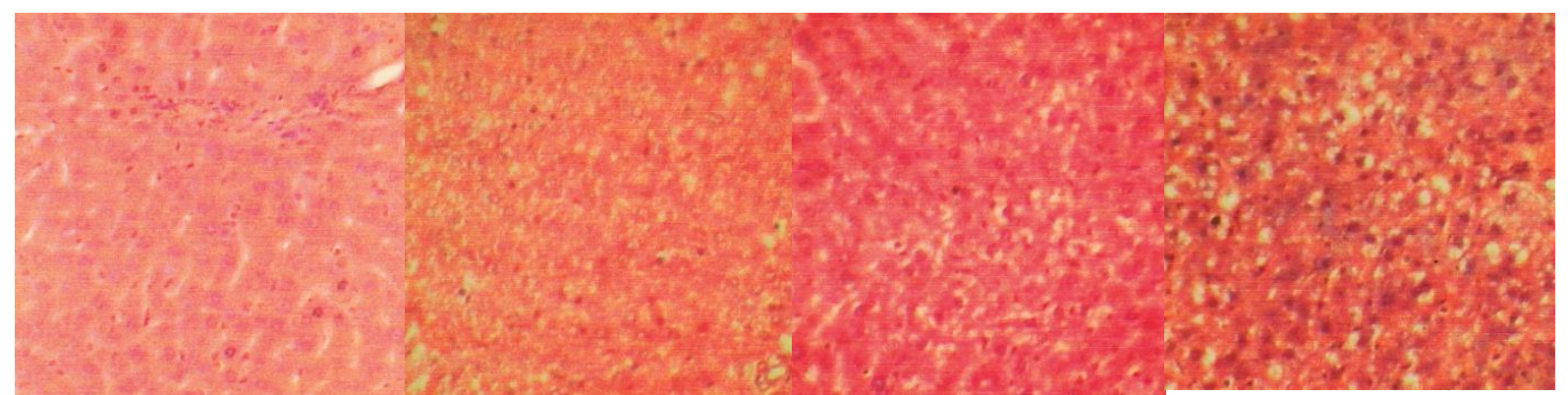

A

B

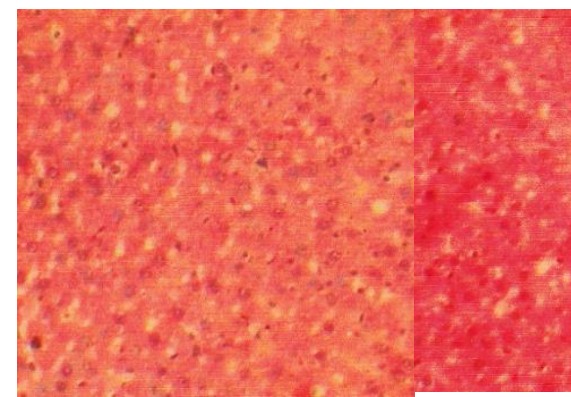

$\mathbf{E}$
C

D

Figure 2. A. Section of Liver of rat standard diet showing normal histology, B. Section of Liver of rat on $\mathrm{NaCN}$ solution for 30 days showing diffuse degenerative change, $\mathbf{C}$. Section of liver of rat fed on apricots seed for 30 days showing periportal degenerative change, D. Section of liver of rat fed on cassava root for 30 days showing diffuse degenerative change, E. Section of liver of rat 90 days after withdrawal of $(\mathrm{NaCN})$ showing degenerative change in focal areas, F. Section of liver of rat 90 days after withdrawal of Prunus armeniaca seed showing degenerative change in focal areas, G. Section of liver of rat 90 days after withdrawal of Manihot esculenta root showing persistance of the degenerative change in the periportal and perilbolar area, H. Sections of kidney of rat showing normal histology.

\section{References}

[1] Devi, L.K. and Singh, P.K., 2013, Proximate Composition of Phenolic Compounds and Vitamin C with Potential Antioxidant activity in selected Rosaceae fruits of Manipur. NeBio, 4(5): 33-38.

[2] Devi, L. K.; Devi, M. H. and Singh, P. K., 2018, Hydrogen Cyanide and other AntiNutritional contents of Some Edible Plant Parts Commonly available in Manipur, International Journal of Current Advanced Research (IJCAR), 7(B): 13996-14002, DOI: http://dx.doi.org/10.24327/ijcar.,2018.9191.1508.

[3] WHO, 1996, World Health Organization Technical Series: Trace elements in human nutrition and health. World Health Organization Geneva; 199-205. 
[4] Jones, D.A., 1988, Cyanogenesis in animal-plant interactions. In D. Evered, S. Harnett, eds., Cyanide Compounds in Biology, Ciba Foundation Symposium No 140, John Wiley \& Sons.

[5] Jones, D.A., 1998, Why are so many plants cyanogenic? Phytochemistry, 37: 477-492.

[6] Nahrstedt, A. Cyanogenic compounds as protecting agents for organisms. Plant Syst Evo. 1985, 150: 35-47.

[7] Gleadow, R.M. and Woodrow, I. E., 2002, Constraints on effectiveness of cyanogenic glycosides in herbivores defense. J.Chem. Ecol., 847-858.

[8] Harbone, J.B., 1972, Cyanogenic glucosides and their function. In: Phytochemical ecology, London Academic Press, p. 104-123.

[9] Lieberei, R.; Selmar, D. and Biehl, B., 1985, Metabolization of cyanogenic glucosides in Hevea brasiliensis. Plant Syst Evol, 150: 49-50.

[10] Andersen, M.D. Busk, P.K. Svendsen, I. and Moller, B.L., 2000, Cytochromes P-450 from cassava (Manihot esculenta crantz) catalyzing the first steps in the biosynthesis of the cyanogenic glucosides linamarin and lotaustralin: Cloning, functional expression in pichipastories and substarate specificity of the isolated recombinant enzymes. J. Biol. Chem., 275: 1966-1975.

[11] Forslund, K. \& Johnson, L., 1997, Cyanogenic glycosides and their metabolic enzymes in barley, in relation to nitrogen levels. Physiol Plant., 101: 367-372.

[12] Neilsen, L.A. Dsen, C.E. Pantoppidan, K. and Moller, 2002, Leucine derived cyanoglycosides in barley. Plant physiol., 129: 1066-1075.

[13] Ologunde, M.O., Olaniyan, S.A., Fapojuwo, O.O., Liasu, M.O. and Olunlade, B.A., 2008, Haematological parameters on rats fed on prolonged crude oil contaminated cassava- based diet. American-Eurasian Journal of Sustainable Agriculture, 2(3): 242- 248.

[14] Gurr, E., 1953, A practical manual of medical and biological techniques, Leonard Hill Ltd, London.

[15] Al-Ghanim, K.A., 1984, Malathion toxicity in Nile tilapia, Oreochromis niloticus - A haematological and biochemical study. Afr. J. Agr. Res., 2012, 7: 562- 567.

[16] Dacie, J.V. and Lewis, S.M., 1984, Practical haematology. $6^{\text {th }}$ ed. London: Churchill Livingstone.

[17] Olusi, S. O.; Oke, O. L. and Odusote, A. C., 1979, Effects of cyanogenic agents on reproduction and neonatal development in rats, Biol. Neonate, 36: 233-293.

[18] Kamalu, B. P., 1995, The adverse effects of long term cassava (Manihot esculenta crantz), Consumption. International journal of Food Science and Nutrition, 46:65-93.

[19] Aliero, A. A.; Okekporo, S. and Maigiwa, M. I., 2011, Toxicoliogical Evaluation of Phyllanthus pentandrus Aqueous Extract on Hepatorenal Functions in Albino Rats. $J$. Pharm. Biomed. Sci., 1(2) 29-33.

[20] Jadab, R., Bora, A., Reddy, P.V.B. and Dwivedi, S. K., 2020, Occurrence of Toxigenic Microcystis spp. in Major Water Bodies of North-East India, Defence Life Science Journal, 5 (2): 87-92, DOI : 10.14429/dlsj.5.15596 (C) 2020, DESIDOC. 